\title{
A Study on the Digital Integrated Platform of China Participatory Rural Community Informationization
}

\author{
Hong Zhou ${ }^{1, *}$, Guangsheng Zhang ${ }^{1}$, Xin Ning $^{2}$, and Jin Luo ${ }^{1}$ \\ ${ }^{1}$ Economic Management College of Shenyang Agricultural University, \\ Shenyang, Liaoning Province, P.R. China 110161, \\ Tel.: +86-24-88487153; Fax: +86-24-88487248 \\ zhouhong003@163.com \\ ${ }^{2}$ Information Centre of Shenyang Agricultural Economic Committee, \\ Shenyang, Liaoning Province, P.R. China 110024
}

\begin{abstract}
Agriculture informationization is the inevitable trend of the world modern agricultural development, at present it is the most main bottleneck that rural informationization progress is slow in the course of Chinese rural informationization development, the last kilometer becomes a difficult problem to solve urgently. Based on the theory of participatory rural community, this article lead to analyze the core reason why exits the endocardial power deficiency of the last kilometers problem in China rural community and the restraint obstruct to the exterior intervention impetus function, researching the original data gained by agricultural informationization investigations and studies in Liaoning Province, and moreover proposes the effective solution is that a Digital integrated platform should be build in China rural community, which play two aspect of the function meanwhile the rural community management and information service, marking a feature of extreme interactivity, integrativity and comprehensive consistent, furthermore it should choose a specific informationization construction plan according to the different community characteristic together with the farmer and the rural community in view of establishing a reasonable effective development mechanism, realizing the fair and reasonable disposition and management to the information resource, ultimately realizing the sustainable development of the rural informationization.
\end{abstract}

Keywords: participatory rural community informationization, digital integrated platform.

\section{A Last Mile Problem in China's Agricultural Informationization: Based on the Survey of Liaoning Province}

The research team has carried on a investigation in August 2008 about rural informationization condition in different village area of Liaoning Province, Investigated more than 800 households in rural households, which drew a following conclusion:

\footnotetext{
${ }^{*}$ Corresponding author.
} 


\subsection{Farmers Gain the Information Still Based in the Traditional Method}

The peasant household generally gains the information by television, villager dissemination, and the village technical talent, SMS, newspaper, magazine as well as the Internet. $96.46 \%$ of peasant households through TV gain information, $60.17 \%$ of peasant households gain information by depending on villager dissemination.

\subsection{Farmers Cannot Timely and Full Make Access to the Technology That Agricultural Production Needs}

Peasant household gains agricultural production technology mainly from TV, Broadcast and Newspaper, secondly from farm technology station or the village model household. It stands a few proportions through network to gain agricultural technology, which depends on the lower volume of computer in rural households.

The peasant household like to listen and watch such TV \& Radio program as CCTV news, CCTV Agricultural program, Black Earth, Law Online, Weather Forecast and so on. Farmer pays more attention to changes in weather and in national rural policy very much, because it relates to their production behavior.

Every year peasant can accept technology training that is organized by county and township farm technology station. The farmer is generally good response to the training, but the training time is short and pertinence is not enough strong. Tab Survey how Farmer obtain production technology unit: household, \%

\begin{tabular}{cccccccc}
\hline City & Item & 1 & 2 & 3 & 4 & 5 & 6 \\
\hline Shenyang & sample size & 54 & 85 & 17 & 59 & 57 & 61 \\
& proportion & 47.79 & 75.22 & 15.04 & 52.21 & 50.44 & 53.98 \\
\multirow{2}{*}{ Anshan } & sample size & 8 & 37 & 20 & 31 & 19 & 22 \\
& proportion & 20.51 & 94.87 & 51.28 & 79.49 & 48.72 & 56.41 \\
Chaoyang & sample size & 25 & 18 & & 8 & 8 & 10 \\
& proportion & 69.44 & 50.00 & & 22.22 & 22.22 & 27.78 \\
\multirow{2}{*}{ Tieling } & sample size & 25 & 23 & 1 & 9 & 13 & 11 \\
& proportion & 73.53 & 67.65 & 2.94 & 26.47 & 38.24 & 32.35 \\
\multirow{2}{*}{ Dandong } & sample size & 11 & 25 & 4 & 18 & 11 & 12 \\
& proportion & 32.35 & 73.53 & 11.76 & 52.94 & 32.35 & 35.29 \\
\hline
\end{tabular}

1. hand down one generation after one another 2.TV, Radio, Newspaper 3.Internet 4.agro-technical station 5.village model household 6.Rural Cadres 7.SMS

\subsection{The Peasant Household is in an Information Inferiority Status in Agricultural Product Sales}

An investigation found that the peasant household has a broad marketing channel, and it's have no difficult to sale the agricultural product. Being not grasp the market information accurately, or being at the inferiority position in business, famer have to accept the purchase business in a low price, thus has affected enhancement income of peasant household. The peasant household gains selling price information mostly by 
the way of dissemination between neighbor villager, accounts for $38.05 \%$; secondly by querying price in the market, accounts for $32.14 \%$; Inquiring to the old customer and searching in the internet accounts for $18.58 \%$ separately and $4.42 \%$. When carrying on the agricultural product sale, however the peasant household was at the weak trend position, they could not adjust price according to market quotation to sales situation.

\subsection{Information Acquisition Is an Important Influence Factor to the Peasant Household Income}

Result of study shows, peasant household thought the primary factor which hinder the improvement of their income include the education level, the information factor, the geography factor, the policy factor and market price. $52.21 \%$ of peasant households thought that they are not good able to increase income by grasping market information.

\subsection{The Peasant Household Underuse Information Service Project of Government}

The peasant household is not very satisfied about the village information officer who uploads and downloads information that they require indeed. Regarding whether village information officer could promptly upload or download the information for the peasant household, which they require indeed, $4.42 \%$ of answer of peasant thought very unprompted, $5.31 \%$ of peasant households thought not prompt, $16.81 \%$ of peasant households think neutral, $25.66 \%$ of peasant households thought quite promptly, $16.81 \%$ of peasant households think not clearly.

The peasant household is not satisfied with village information officer, $28.85 \%$ of peasant households thought strongly unsatisfied, $35.40 \%$ of peasant households think satisfied. The peasant household thought they would seek such information as seed, chemical fertilizer and other rural purpose commodity through the information officer, which stand $58.41 \%$ of all opinions. $46.90 \%$ and $41.59 \%$ of peasant household hope through the village information station they could order agricultural books or the agricultural insurance, but at present this kind of service not have done.

Since the national uniform agricultural service hotline 12316 has been established, a new channel is opened to the farmers to consult information, which enables the farmer to be possible obtaining consultation about agricultural production, management and so on from the expert; it is a very good kind of rural information service pattern. However, among 113 peasant households which accepted survey there were only 6 households who have used the agricultural information expert system hotline 12316, the above-mentioned survey indicated that rural information service hotline 12316 Needs to strengthen vigorous promotion.

\section{Analyzes about Reason of the Last Mile Problem of Rural Informationization in China Village}

\subsection{Endogenous Deficient in Motivation}

Participatory theory think that development is internal change in the social economy system, because it does not impose from exterior but occurs voluntarily from interior, 
development motivation supply from the subjective activity itself, outside assistant is only an incentive means, which couldn't substitute for the subjective activity itself of development. The participation essence lies in undertake, share, and altogether takes on risk.

At present, the main reason why agriculture informationization progress in Chinese village seems slow is that farmer plays main roles in agricultural production and management, however they lie in the passive position actually in the agricultural informationization practice, the farmer does not grasp the technology, the resources and the project, in additional they are in a lower education level, and then the administrative order and the expert is in the dominant position in the informationization project promotion, whereas the agricultural information provided for the peasant in the existing rural information service channel is poor targeted, and lack of integration of practical information resources, poor interactive information channel, in short it's in urgent need of change to this kind of situation in order to develop modern agriculture.

\subsection{Exterior Intervention Impetus Function Occurs the Restraint Barrier}

In participatory development pattern, the participant includes the villagers, as well as the governmental organization, technical department, non-governmental forces and so on. The core factor of participatory countryside development approach is how to develop human and talent resources, to transform role, to enhance communication, exchange and dialogue. It should devolve authority of voice, analyze, decision and management to the localities and the people, the concerned outside factor is the catalyst, which assist to develop countryside and transform process.

At present, the agricultural information dissemination system mainly is both at higher and lower levels, which generally terminates at county level or at the villages and towns government department, they usually carry on the hardware and software construction deferring to the request, however regarding the final practical information needed to peasant household, there have not been established an inspected KPI and clear request.

Moreover, the dispersive distribution characteristics of village brings certain difficulty to gather and update information, in some areas the concurrent-jobpersonnel manages the software and hardware system, even if there is the full time personnel to manage, regarding in practical information gathering and processing for peasant household, then the less time and cost be spend. Some information provided by department officer mutually reprints and duplicates that seems extremely high duplication and lower usability. Because the above-mentioned information resource is dispersible, nonsystematic, overlapping and duplicated, which does not carry authority, result of that sometimes peasant household thought themselves into a dilemma. Being characterized by poor practicability for application, lack of pertinence, less information that the farmer most cared about, the peasant household made lower satisfaction rate of comment on government information service degree, some farmers even more entirely do not catch existence of the government information department, also some has not obtained the corresponding information service. 
Sometimes the government officer and the expert penetrate to the village to provide some training, in somewhat system reason the experts are not impossible to systematically and persistently carry on instruction in the village basic unit, therefore it was not enable to guarantee training to be practical and conform to the farmer season, in quantity cannot satisfy the farmer's need.

Being above reason external force intervention impetus functions such as government, experts and so on is extremely limited to agricultural informationization construction in the village basic unit in long period.

\section{Effective Solution of Last Mile Problem: Built the Digital Integrated Platform of China Participatory Rural Community Informationization}

It is extremely vital significance to solve the village last mile problem to Apply Participatory Rural development theory in agricultural informationization domain, to rebuilt participatory village agriculture informationization service pattern, to establish an unified comprehensive information service platform that extend truly to the township, the village and the peasant household, in turn enabling each peasant household to be possible to interact truly the participation, and to change the situation of top-down one-way information dissemination in village.

\subsection{Project Plan of Participatory Rural Digital Integrated Platform}

The peasant household starts to involve the project from the beginning of plan definition, and should pass through the whole process in the project cycle, recharging monitor and appraisal to involved shareholders in the project construction and implementation. The main important difference of the general monitor and an appraisal is that peasant household not only provides the information for the monitor appraisal, moreover they are also responsible to collect and analyze information, and therefore it is benefit in enhancing their participation and application consciousness.

\subsection{Character of Participatory Rural Digital Integrated Platform}

\subsubsection{Be Great Strengthened Interactive and Information Is Comprehensive and Timely}

Each villagers may registry as a member, who enjoys the corresponding member service and own mailbox, who can issue circulation of the land, the agricultural product sales, purchase and transfer of the agricultural material, life consumable product purchase and transfer through BBS (forum). Blogs: Every peasant register may open Blog space, where they introduce the agricultural product sale information in detail; information station may issue promptly some policies, the laws and regulations, the meteorological information, news and so on by sending SMS, enabling farmer to be possible to promptly obtain the news most cared about, as well as such information as health, entertainment, rural education and so on. 


\subsubsection{Be Good at Powerful Integration}

This platform has powerful function to enable E-commerce, accomplishing the opportunity to the both sides of seller and buyer to sell and buy agricultural materials and product. The platform integrates ERP system of the agricultural enterprise, the agricultural materials manufacturer, the distributor and business agent, enables the farmer to be possible to learn such information as farming, crops grow, prevention of plant disease, the agricultural material and product business and market, preventing themselves be deceived and so on through the computer and the network. At the same time, the platform has definite advantage to rebuilt and improve the countryside basic database, to broaden the application space, to develop alerting monitor system for quality and safety of agricultural products, agricultural product market supply and demand system, management system of rural labor force migration, agricultural product safety traceability system, realizing issue and inquiry of agricultural product supply and demand, quality and safety of agricultural products and so on.

\subsection{Content of Participatory Rural Digital Integrated Platform}

The system mainly has two big main functions of countryside management and agricultural information service, it connects and shares with all levels of agricultural information network resources, taking adequate advantage of computer, television, telephone, broadcast, SMS and so on to rebuilt the information network platform The Digital Village That serves for three agriculture, countryside and peasant, in order to form the information network that can link the province, city, county, township, and village. In all counties (city), towns and village will setup the subnet. By subnet the information about the county, towns, and villages as well as the information of various levels of commission will be browsed. On the subnet the pages Agricultural Product Information will be set up, the related department will take charge of uploading such local information as agricultural product output, price and so on at the right moment, which put up the bridge to moves towards the agricultural product to the market. The system covers all countryside information network service system, realizing purpose "every township has the website, every village has the homepage". Through the homepage any information such as natural resource, the appearance, infrastructure, farmhouse, school and so on should be browsed, including all king of form demonstration such as picture, movie and text. All levels of enterprises, the association, the cooperative society and other specialty industries also should display the corresponding multimedia demonstration, at the same time such item as village economical situation, infrastructure, social undertaking and local folk custom should be displayed in multimedia form.

\subsection{The Guarantee Mechanism for Digital Integrated Platform of Participatory Rural Community Informationization}

\subsubsection{Establishment of the Perfect Personnel Training for Participatory and Sustainable Rural Informationization Development}

To establish agriculture informationization training mechanism, it should involves all levels of personnel in view of the basic unit agricultural informationization integrated digital platform to establish the suitable training plan, paying more attention to entirely receiving training personnel to participate. 


\subsubsection{Participatory Rural Informationization Management}

The key function of integrated digital platform mainly includes countryside management and rural information service. Firstly it should promote countryside management informationization, and carry out an advanced management method in informationization fields, guaranteeing the smooth realization of informationization function in countryside information service.

\subsubsection{Comprehensive Utilization of Many Kinds of Media Form}

Facing to the various educational levels of farmers to provide service, it must unify organically the traditional media and many kinds of modernized media, it should play radiating and impetus function of main item enterprise, the planting and cultivating peasant, the professional association, the cooperative organization and the broker troop. 